\title{
Glutamate Transport and Production in Brevibacterium flavum
}

\author{
Michiko Mori and Isamu SHIIO \\ Central Research Laboratories, Ajinomoto Co. Inc., \\ Kawasaki-ku, Kawasaki, Kanagawa 210, Japan
}

Received September 20, 1982

\begin{abstract}
L-Glutamate was taken up and concentrated into washed cells of Brevibacterium flavum, a glutamate-producing bacterium. Potassium ions specifically promoted the uptake rate. The uptake activity in the presence of $\mathrm{K}^{+}$was inhibited by carbonyl cyanide- $m$-chlorophenyl hydrazone but not by $N, N^{\prime}$-dicyclohexylcarbodiimide, $\mathrm{NaN}_{3}$, ouabain, valinomycin or gramicidin. The activity was specifically and competitively inhibited by L-aspartate among L-amino acids but not so strongly by other structural analogues including D-glutamate. L-Aspartate uptake was also competitively inhibited by L-glutamate. Michaelis constants for glutamate and aspartate were 19 and $25 \mu \mathrm{M}$, respectively. The glutamate uptake activity of the cells increased when $\mathrm{NH}_{4}{ }^{+}$in the culture medium was reduced. Five out of six mutants which were unable to grow on glutamate and produced more glutamate than the parent showed a lower maximum rate of uptake than the parent.
\end{abstract}

It has previously been shown that a glutamate-producing bacterium, Brevibacterium flavum, grew on L-glutamate as the sole carbon and nitrogen source and that some mutants unable to grow on glutamate showed approximately $10 \%$ higher productivity than the parent. Because these improved producers had all the glutamate metabolizing enzymes tested, they were suggested to be defective in glutamate uptake activity. ${ }^{1)}$

In contrast to other amino acids, glutamate is overproduced by a special mechanism, in which a permeabilized cell membrane is formed under special culture conditions, and then glutamate formed is rapidly excreted to the outside medium, so that the intracellular glutamate concentration is maintained low enough for the feedback control of the biosynthesis not to operate. ${ }^{2 \sim 7)}$ Therefore, a further decrease in the intracellular glutamate concentration at steady state seems to increase the glutamate production. Because this concentration depends on the uptake rate of excreted glutamate as well as the rates of biosynthesis and excretion, it seems reasonable that a decrease in the glutamate uptake activity results in reduction of the intracellular glutamate concentration and in an increase of the glutamate formation.

The present paper reports some properties of the glutamate uptake activity and its decrease in the improved glutamate producers reported previously.

\section{MATERIALS AND METHODS}

Bacterial strains and culture media. Brevibacterium flavum No. 2247 (ATCC 14067), isocitrate-lyase defective mutant $1646^{8}$ derived from No. 2247, and mutants unable to grow on glutamate, Nos. 741, 751, 753, 106 and $727^{1)}$ derived from No. 2247 and $112^{11}$ derived from 1646, were used. Media $7,{ }^{6)} 20,{ }^{9)} 22,{ }^{9)}, 2^{1)}$ and $32^{10)}$ were described previously.

Chemicals. L- $\left[\mathrm{U}-{ }^{14} \mathrm{C}\right]$ Glutamic acid and $\mathrm{L}-\left[\mathrm{U}-{ }^{14} \mathrm{C}\right]-$ aspartic acid were obtained from the Radiochemical Centre, Amersham. Omnifluor was purchased from New England Nuclear. The other amino acids and amino acid analogues were obtained from Ajinomoto Co., Calbiochem, Chemical Dynamics and Sigma Chemical Co. Valinomycin and ouabain were purchased from Boehringer Mannheim $\mathrm{GmbH}$, and gramicidin $\mathrm{D}$, carbonyl cyanide- $m$-chlorophenyl hydrazone (CCCP) and $N, N^{\prime}$-dicyclohexylcarbodiimide (DCCD) from Sigma Chemical Co.

Determination of glutamate uptake activity. B. flavum

Abbreviations: CCCP, carbonyl cyanide- $m$-chlorophenyl hydrazone; DCCD, $N, N^{\prime}$-dicyclohexylcarbodiimide. 
No. 2247 (growth: about 0.5 ) and mutants grown at $30^{\circ} \mathrm{C}$ for $16 \mathrm{hr}$ with shaking in $50 \mathrm{ml}$ of medium 20 were harvested by centrifugation, washed three times with $50 \mathrm{ml}$

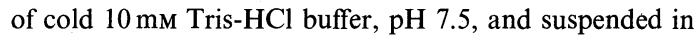
the same buffer. After 10 or $20 \mathrm{ml}$ of the cell suspension was shaken in a $500 \mathrm{ml}$-flask at $30^{\circ} \mathrm{C}$ for $1 \mathrm{hr}$, the cells were harvested and resuspended in the same buffer. Absorbancy of the suspension was adjusted to 0.1 or 0.2 at $562 \mathrm{~nm}$ after 750-fold dilution. The standard assay mixture contained $10 \mathrm{~mm}$ Tris- $\mathrm{HCl}$ buffer, $\mathrm{pH} 7.5,10 \mathrm{~mm} \mathrm{KCl}$ and $0.05 \mathrm{ml}$ of the cell suspensions prepared as above in a final volume of $0.5 \mathrm{ml}$, and was preincubated at $30^{\circ} \mathrm{C}$ for $3 \mathrm{~min}$ before $0.05 \mathrm{ml}$ of labeled glutamic acid (specific activity; $10 \mu \mathrm{Ci}$ / $\mu \mathrm{mol}$ ) was added at a final concentration of 20 or $100 \mu \mathrm{M}$. Immediately and $2 \mathrm{~min}$ after the addition, $0.1 \mathrm{ml}$ aliquots of the mixture were taken and the cells were collected on membrane filters (pore size, $0.45 \mu \mathrm{m}$; diamiter, $25 \mathrm{~mm}$; Toyo Filter Paper Co.) by vacuum filtration. The retained cells were immediately washed six times with $1 \mathrm{ml}$ of cold $10 \mathrm{~mm}$ Tris- $\mathrm{HCl}, \mathrm{pH} 7.5$. The cells on a membrane filter were dried under an infrared lamp for about $1 \mathrm{hr}$ and then placed in a glass scintillation vial containing $10 \mathrm{ml}$ of a scintillation cocktail consisting of $4 \mathrm{~g}$ of omnifluor and 1 liter of toluene. Then, radioactivity of the cells was measured with a Beckman Liquid Scientillation Counter, model LS-133. The amount of glutamate uptake was given by radioactivity incorporated into the cells in $0.1 \mathrm{ml}$ of the reaction mixture.

Other procedures. Growth was determined by measuring absorbancy at $562 \mathrm{~nm}$ after 26-fold dilution. Glucose was determined colorimetrically with glucose oxidase, using a Glucose B-Test purchased from Wako Pure Chemical Industries.

\section{RESULTS}

Effects of aeration and time course of glutamate uptake in aerated cells

For the determination of glutamate uptake activity, the cells grown in medium 20 , which was a glutamate producing medium supplemented with excess biotin, were used in order to prevent excretion of glutamate accumulated intracellularly. As shown in Fig. 1, glutamate uptake activities were greatly affected by the growth phase of cells when the cell suspensions were not aerated before the assay. This may be attributed to differences in the level of the intracellular glutamate pool and in the protein synthetic activities. However, when the washed cells were aerated for $1 \mathrm{hr}$, the uptake activities of cells harvested at various growth phases approximated

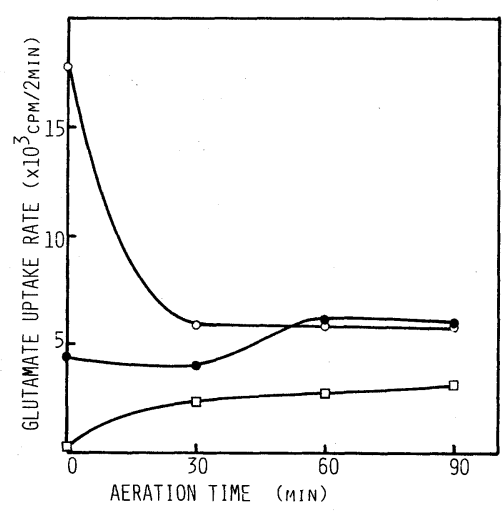

FIG. 1. Effect of Aeration on Glutamate Uptake.

Various amounts of B. flavum No. 2247 cells grown in medium 7 were inoculated into medium 20 and aerobically cultured with shaking at $30^{\circ} \mathrm{C}$ for $16 \mathrm{hr}$. Growth in the culture broth was respectively 0.116 ( $-\mathrm{O}-), 0.405$ (- - ) and 0.600 ( $-\square-$ ). Ten $\mathrm{ml}$ of the washed cell suspension was shaken in a $500 \mathrm{ml}$-flask at $30^{\circ} \mathrm{C}$ for the times indicated in the figure. The reaction mixture $(0.5 \mathrm{ml})$ contained ${ }^{14} \mathrm{C}$-glutamate at a final concentration of $100 \mu \mathrm{M}$ and $0.05 \mathrm{ml}$ of cell suspension whose concentration was about 0.2 ( $A_{562}$ after 750 -fold dilution). The glutamate uptake rate was normalized to that with a cell suspension at a concentration of 0.200 .

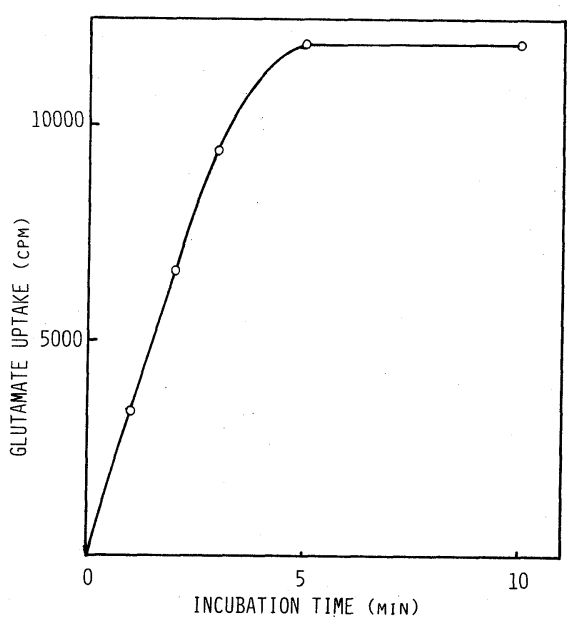

FIG. 2. Time Course of Glutamate Uptake by Aerated Cells.

Glutamate uptake was determined at the times given in the figure as described in MATERIALS AND METHODS except that the concentration of glutamate in the reaction mixture was $20 \mu \mathrm{M}$ and the concentration of the cell suspension was 0.086 ( $A_{562}$ after 750 -fold dilution). Glutamate uptake is shown as that of radioactivity into the cells in $0.1 \mathrm{ml}$ of the reaction mixture $(1 \mathrm{cpm}=1.08 \mathrm{dpm})$. 
to a definite value, and the results were reproducible. Therefore, aerated cells were used in subsequent experiments. Figure 2 shows the time courses of glutamate uptake by the aerated cells. Under the standard conditions ( $20 \mu \mathrm{M}{ }^{14} \mathrm{C}$-glutamate), the uptake reaction proceeded linearly up to $4 \mathrm{~min}$ then reaching the maximum. In view of this, a 2 min reaction time was selected for the subsequent standard conditions.

The maximal'glutamate uptake corresponded to $29 \%$ of the total amount of glutamate in the reaction mixture, and also to $338 \mathrm{nmol} /$ $\mathrm{ml}$ wet cell paste, indicating that the intracellular concentration of glutamate was at least 24 times higher than the extracellular concentration.

\section{Stimulation by $\mathrm{K}^{+}$}

As shown in Table $\mathrm{I}$, addition of $\mathrm{K}^{+}$to the reaction mixture resulted in more than a 10 fold increase in the glutamate uptake. A slight increase in the uptake also occurred with $\mathrm{Na}^{+}$, whereas no stimulation was observed when $\mathrm{Li}^{+}, \mathrm{Rb}^{+}$or any other cations were added.

\section{TABle I. EFFects of INOGRanic SALTS on Glutamate Uptake}

After $3 \mathrm{~min}$ incubation of the reaction mixture in the presence of the indicated salt, the reaction was started by the addition of ${ }^{14} \mathrm{C}$-glutamate (final concentration, $20 \mu \mathrm{M}$ ). The concentration of the cell suspension added to the reaction mixture was between 0.138 and 0.168 and the uptake rate without addition was between $9.7 \times 10^{-6}$ and $2.2 \times 10^{-5} \mu \mathrm{mol} / \mathrm{min} / 0.1 \mathrm{ml}$-reaction mixture.

\begin{tabular}{lcc}
\hline Addition & $(\mathrm{mm})$ & Relative uptake rate \\
\hline $\mathrm{None}$ & & 1.0 \\
$\mathrm{KCl}$ & 1 & 11.5 \\
& $10^{*}$ & 12.1 \\
$\mathrm{NaCl}$ & 1 & 1.9 \\
& 10 & 3.4 \\
$\mathrm{MgCl}_{2}$ & 10 & 1.2 \\
$\mathrm{MnCl}_{2}$ & 10 & 0.45 \\
$\mathrm{FeCl}$ & 10 & 0.76 \\
$\mathrm{CaCl}_{2}$ & 10 & 1.7 \\
$\mathrm{RbCl}_{\mathrm{LCl}}$ & 10 & 1.5 \\
$\mathrm{LiCl}$ & 10 & 1.2 \\
$\mathrm{NH}_{4} \mathrm{Cl}$ & 10 & 0.89 \\
\hline
\end{tabular}

* The standard conditions are described in MATERIALS AND METHODS.
Figure 3 shows that the stimulatory effect was saturated at $3 \mathrm{~mm} \mathrm{KCl}$. The double reciprocal plots in Fig. 4 show that $\mathrm{K}^{+}$and $\mathrm{Na}^{+}$stimulated the glutamate uptake by increasing the maximal rate but did not affect the affinity for glutamate. In the subsequent experiments,

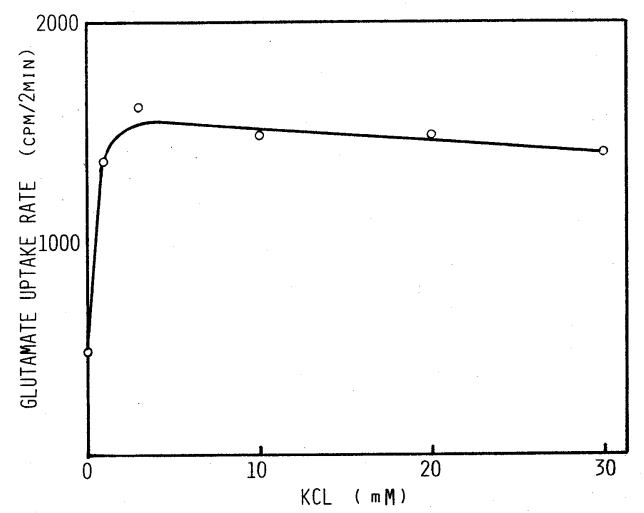

FIG. 3. Effect of $\mathrm{KCl}$ Concentration on Glutamate Uptake.

The assay method was the same as in Table I except that the concentration of the cell suspension was $0.168\left(A_{562}\right.$ after 750 -fold dilution).

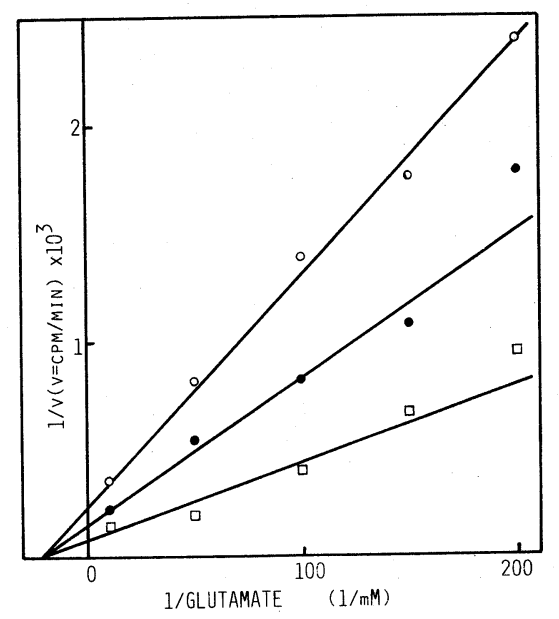

FIG. 4. Double-reciprocal Plots of Glutamate Uptake Rate against Glutamate Concentration in the Presence and Absence of $\mathrm{KCl}$ or $\mathrm{NaCl}$.

The reaction mixture contained the given concentration of glutamate and $10 \mathrm{mM} \mathrm{KCl}(-\square-)$, the standard conditions, $10 \mathrm{~mm} \mathrm{NaCl}(-\bigcirc-)$, or none (- - -) instead of $\mathrm{KCl}$. The concentration of the cell suspension added to the reaction mixture was 0.200 ( $A_{562}$ after 750 -fold dilution). The reaction was carried out for $1 \mathrm{~min}$. The other conditions were the same as described in MATERIALS AND Methods. 
glutamate uptake was determined in the presence of $10 \mathrm{~mm} \mathrm{KCl}$ unless otherwise stated.

\section{Effects of energy sources, metaboric inhibitors and ionophores}

As described already, glutamate uptake by B. flavum No. 2247 was an active process, by which glutamate was concentrated in the cells, indicating an energy requirement. In fact, the reaction remarkably depended on the temperature as shown by the experiment at $0^{\circ} \mathrm{C}$ in Table II. Moreover, CCCP, an uncoupler of the oxidative phosphorylation, inhibited the glutamate uptake almost completely at $50 \mu \mathrm{M}$. On the other hand, glucose or acetic acid that seemed to supply energy on rapid degradation inhibited the glutamate uptake. In addition, neither $\mathrm{NaN}_{3}$, a respiratory inhibitor, DCCD, an $\mathrm{H}^{+}$-ATPase inhibitor, nor ouabain, an inhibitor of $\mathrm{Na}^{+} \cdot \mathrm{K}^{+}$-ATPase, which had been found to exist generally in animal cells, affect-

TAble II. EFFects of Energy Sources, METABOLIC INHIBITORS AND IONOPHOROUS Antibiotics on Glutamate Uptake

After $3 \mathrm{~min}$ incubation of the assay mixture in the presence of each addition indicated below, the reaction was started by the addition of ${ }^{14} \mathrm{C}$-glutamate (final concentration, $20 \mu \mathrm{M}$ ).

\begin{tabular}{lcr}
\hline \multirow{1}{*}{ Addition } & & Glutamate uptake \\
\cline { 3 - 3 } & & Relative rate* \\
\hline None & & 100 \\
None (Incubation at $\left.0^{\circ} \mathrm{C}\right)$ & & 8 \\
Glucose & 10 & 41 \\
& 50 & 23 \\
K-Acetate & 10 & 20 \\
& 50 & 4 \\
NaN & & 94 \\
Valinomycin & 30 & 86 \\
Gramicidin D & 0.001 & 98 \\
Ouabain & 0.001 & 92 \\
CCCP & 1.0 & 29 \\
& 0.005 & 8 \\
DCCD & 0.05 & 66 \\
& 0.05 & 73 \\
\end{tabular}

* Relative rate: $100=15519$ to $17688 \mathrm{cpm} / 2 \mathrm{~min}$ $0.1 \mathrm{ml}$-reaction mixture for valinomycin, gramicidin D, ouabain, CCCP and DCCD; $100=1539 \mathrm{cpm} / 2$ $\mathrm{min} / 0.1 \mathrm{ml}$-reaction mixture for additions other than those above. ed the glutamate uptake. The uptake was also not inhibited by a $\mathrm{K}^{+}$-specific ionophore, valinomycin, or a cation ionophore, gramicidin. This indicated that glutamate uptake does not depend on the $\mathrm{K}^{+}$concentration gradient between extra- and intra- cellular space.

\section{Effects of $\mathrm{L}$-amino acids and glutamate} analogues

Specificity of the glutamate uptake system was examined by the inhibitory effects of Lamino acids and glutamate analogues. Of seven L-amino acids shown in Table III, only an acidic amino acid, L-aspartate, strongly inhibited the glutamate uptake, whereas neither

\section{TABle III. EFFects of L-Amino Acids AND Structural Analogues of Glutamate on Glutamate Uptake}

After $3 \mathrm{~min}$ incubation in the presence of a final $1 \mathrm{~mm}$ of each addition, the reaction was started by addition of $\mathrm{L}-\left[\mathrm{U}-{ }^{14} \mathrm{C}\right]$ glutamate at the final concentration of $20 \mu \mathrm{M}$. The other assay conditions were the same as described in Materials AND Methods. The uptake rates without addition were 10912 and $9955 \mathrm{cpm} / 2 \mathrm{~min} / 0.1 \mathrm{ml}$-reaction mixture in experiments I and II, respectively.

\begin{tabular}{|c|c|c|}
\hline Experiment & Addition & \multirow{2}{*}{$\begin{array}{c}\begin{array}{c}\text { Relative } \\
\text { uptake } \\
\text { rate }\end{array} \\
100\end{array}$} \\
\hline \multirow{8}{*}{ I } & None & \\
\hline & L-Aspartate & 2 \\
\hline & L-Glutamine & 90 \\
\hline & L-Leucine & 79 \\
\hline & L-Alanine & 86 \\
\hline & L-Threonine & 95 \\
\hline & L-Lysine & 99 \\
\hline & L-Phenylalanine & 91 \\
\hline \multirow{13}{*}{ II } & None & 100 \\
\hline & $\alpha$-Methyl-DL-glutamic acid & 62 \\
\hline & $N$-Methyl-DL-glutamic acid & 95 \\
\hline & Glutaric acid & 68 \\
\hline & $L-\alpha$-Aminoadipic acid & 76 \\
\hline & $\gamma$-Aminobutyric acid & 76 \\
\hline & L-Homocysteic acid & 63 \\
\hline & L-Glutamate- $\gamma$-monohydroxamate & 51 \\
\hline & L-Glutamate- $\gamma$-methyl ester & 55 \\
\hline & D-Glutamic acid & 53 \\
\hline & $\begin{array}{l}\text { DL-2-Amino-4-phosphonobutyric } \\
\text { acid }\end{array}$ & 49 \\
\hline & L-Cysteic acid & 55 \\
\hline & $\begin{array}{l}\text { DL-2-Amino-3-phosphono- } \\
\text { propionic acid }\end{array}$ & 43 \\
\hline
\end{tabular}


the amide of L-glutamate, neutral amino acids, L-leucine and L-alanine, basic amino acid, Llysine, aromatic amino acid, L-phenylalanine, nor a $\beta$-hydroxy amino acid, L-threonine, did so. Specific uptake systems for aromatic amino acids and $\beta$-hydroxy amino acids have already been found in this organism. Therefore, the glutamate uptake system seems to be different from those for amino acids other than aspartate. Figure $5 \mathrm{~A}$ and $\mathrm{B}$ shows that glutamate uptake was competitively inhibited by aspartate, while aspartate uptake was inhibited by glutamate. Further, because Dixon plots for aspartate and glutamate inhibition of the glutamate and aspartate uptake, respectively, gave straight lines as shown in Fig. 5C and D, these inhibitions seem to be truely competitive. This indicates that glutamate and aspartate are transported into the cells by a common system.

Table III, shows that no glutamate anal-
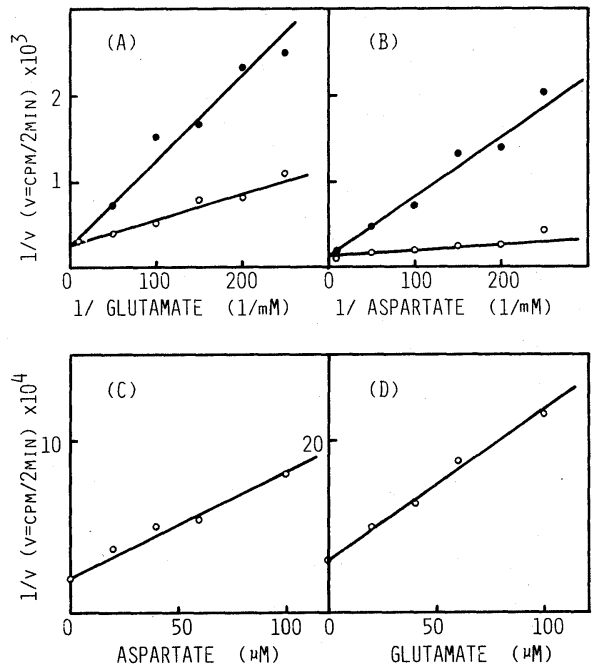

FIG. 5. Kinetic Properties of Glutamate and Aspartate Uptake and of Their Interference.

In (A) and (B), reciprocal uptake rates of glutamate (A) and aspartate (B) are plotted against reciprocal concentration of the substrates in the presence (- - ) and absence (-O-) of $30 \mu \mathrm{M}$ inhibitors, aspartate (A) and glutamate (B), respectively. In (C) and (D), reciprocal uptake rates of glutamate (C) and aspartate (D) at $20 \mu \mathrm{M}$ are plotted against concentration of inhibitors, aspartate (C) and glutamate (D), respectively. The other reaction conditions were the same as given in MATERIALS AND Methods. The concentration of the cell suspension used was 0.210 ( $A_{562}$ after 750 -fold dilution). ogues tested inhibited the glutamate uptake so strongly as aspartate did, indicating that the glutamate uptake system is highly specific for the substrate. From the data in Fig. 5, Michaelis constants $(\mathrm{Km})$ of this uptake system for glutamate and aspartate were calculated to be 19 and $25 \mu \mathrm{M}$, respectively, and the maximum uptake rates $\left(V_{\mathrm{m}} \mathrm{s}\right)$ were $4.1 \times 10^{-4}$ and $3.1 \times 10^{-4} \quad \mu \mathrm{mol} / \mathrm{min} / 0.1 \mathrm{ml}$ (concentration of cell suspension $=0.200$ at $562 \mathrm{~nm}$ after 75 -fold dilution), respectively. These values were almost the same as those of the threonine uptake system, ${ }^{11)} 36 \mu \mathrm{M}$ and $2.8 \times$ $10^{-4} \mu \mathrm{mol} / \mathrm{min} / 0.1 \mathrm{ml}$, respectively.

Glutamate uptake activity and glutamate production in mutants unable to grow on glutamate

Glutamate uptake activities of mutants ${ }^{1)}$ of B. flavum that were unable to grow on glutamate and produced approximately $10 \%$ more than the parent were compared with that of the parent (Table IV). Whereas $\mathrm{Km}$ values of mutants were nearly equal to or slightly higher than that of the parent, $V_{\mathrm{m}}$ values of all mutants except for strain 753 were markedly reduced.

\section{Table IV. Kinetic Constants for Glutamate Uptake ACtivities of Mutants Unable to Grow on Glutamate}

Bacterial strains were cultured and prepared as described in MATERIALS AND METHODS and their glutamate uptake activities were determined under the standard conditions but at various glutamate concentrations. Michaelis constants, $\mathrm{Km}$ and the maximum rates, $V_{\mathrm{m}}$, were calculated from double-reciprocal plots of glutamate uptake rate against glutamate concentration. $V_{\mathrm{m}}$ values were normalized to that with a cell suspension of 0.200 .

\begin{tabular}{ccl}
\hline \multicolumn{1}{c}{ Strain } & $K m(\mu \mathrm{M})$ & $V_{\mathrm{m}}^{*}$ \\
\hline 2247 (Parent) & 19 & 4.1 \\
741 & 71 & 0.27 \\
751 & 59 & 1.8 \\
753 & 45 & 8.0 \\
106 & 20 & 0.17 \\
727 & 125 & 0.12 \\
112 & 13 & 0.17 \\
\hline
\end{tabular}

* $\times 10^{-4} \mu \mathrm{mol} / \mathrm{min} / 0.1 \mathrm{ml}$-reaction mixture. 
Regulation of formation of the glutamate uptake system

Preliminary experiments revealed that glutamate uptake activity of the cells was affected by components of the culture medium. Medium 29 containing glutamate as sole carbon and nitrogen source gave higher activity than did the same medium containing glucose and $\mathrm{NH}_{4}{ }^{+}$instead of glutamate. Although medium 22 containing acetate as a carbon source included $\mathrm{NH}_{4}{ }^{+}$at a higher concentration than did the latter medium, it gave higher activity than the latter medium. These results suggest that formation of the glutamate uptake activity was repressed by glucose and

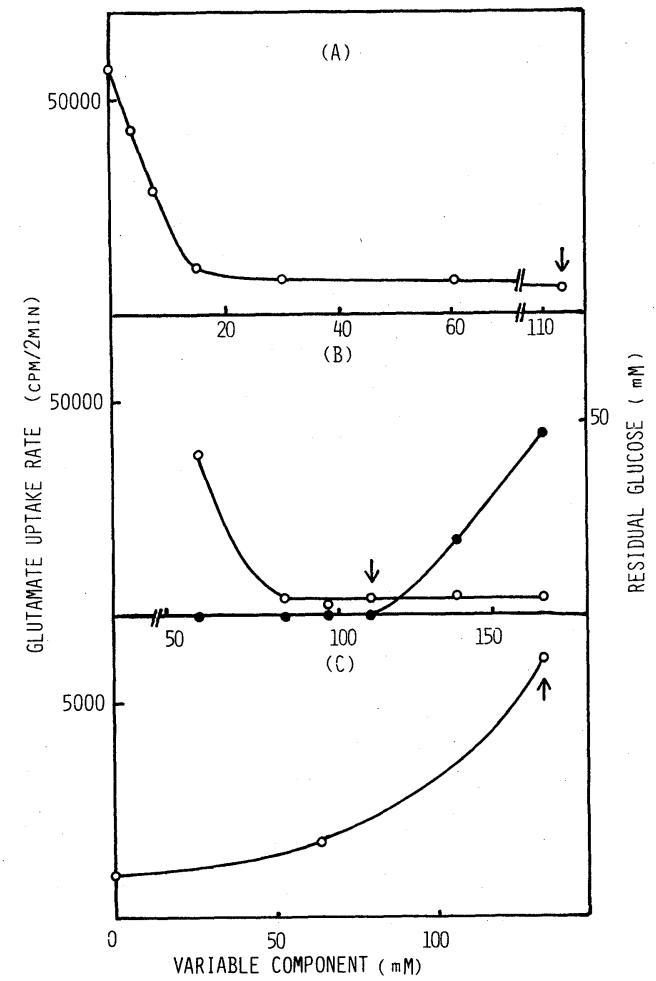

FIG. 6. Effects of $\mathrm{NH}_{4}{ }^{+}$, Glucose and Glutamate Concentrations in the Culture Medium on Glutamate Uptake Activity.

B. flavum No. 2247 was cultured in medium 32 containing the indicated concentration of $\mathrm{NH}_{4}{ }^{+}$(A), glucose (B), or glutamate (C) at $30^{\circ} \mathrm{C}$ for $16 \mathrm{hr}$. A cell suspension was prepared and glutamate uptake was measured as described in MAterials AND Methods. The reaction mixture contained a final $100 \mu \mathrm{M}{ }^{14} \mathrm{C}$-glutamate. Residual glucose in (B) (- - ) was determined. Arrows in the figures show results with the standard culture medium, 32.
$\mathrm{NH}_{4}{ }^{+}$and induced by glutamate. Then, further investigation was carried out as follows. At first, glutamate uptake activity was determined with B. flavum No. 2247, when it was cultured at various concentrations of $\mathrm{NH}_{4}{ }^{+}$, glucose and glutamate, using medium 32 as the standard medium, which contained monosodium glutamate, glucose and $\left(\mathrm{NH}_{4}\right)_{2} \mathrm{SO}_{4}$ as carbon or nitrogen sources. Figure $6 \mathrm{~A}$ and $\mathrm{B}$ shows that reduction of the $\mathrm{NH}_{4}{ }^{+}$or glucose concentration resulted in an increase of the uptake activity. These results suggest that the glutamate uptake system was synergistically repressed by $\mathrm{NH}_{4}{ }^{+}$and glucose. Moreover, as shown in Fig. 6B, derepression at a lower concentration of glucose was observed only after complete consumption of glucose. However, when B. flavum No. 2247 grown in the basal medium (medium 32) described above was transferred to fresh medium 22 containing acetate and $0.3 \mathrm{M} \mathrm{NH}_{4}^{+}$as sole carbon and nitrogen sources, addition of $0.1 \mathrm{M}$ glucose increased glutamate uptake activity considerably (Fig. 7).

Figure $6 \mathrm{C}$ shows that reduction of the gluta-

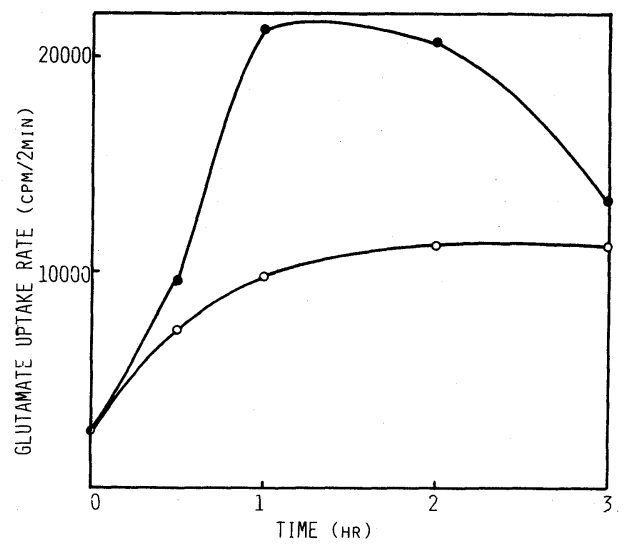

FIG. 7. Effect of Glucose in the Culture Medium on Glutamate Uptake Activity.

After B. flavum No. 2247 was cultured in medium 32 at $30^{\circ} \mathrm{C}$ for $16 \mathrm{hr}$, the cells were suspended in medium 22 (- $\mathrm{O}-$ ) or medium 22 supplemented with $0.1 \mathrm{M}$ glucose (- - ) and $50 \mathrm{ml}$ of the suspension $\left(A_{562}\right.$ after 26-fold dilution: 0.500 ) was cultured in $500 \mathrm{ml}$-flasks at $30^{\circ} \mathrm{C}$ for $3 \mathrm{hr}$ again. Preparation of cells and determination of glutamate uptake were the same as described in $\mathrm{MA}^{-}$ TERIALS AND METHODS except that the reaction mixture contained $100 \mu \mathrm{M}{ }^{14} \mathrm{C}$-glutamate. 
mate concentration in the culture medium brought about a further decrease in the activity which had been repressed by a high concentration of glucose and $\mathrm{NH}_{4}{ }^{+}$. In view of this, it was likely that glutamate uptake activity was induced by glutamate. However, the effect of glutamate was also possibly indirect, because glucose consumption decreases with decreasing glutamate in the culture medium (data not shown). Moreover, as shown in Fig. 7, glutamate uptake activity increased when $B$. flavum No. 2247 grown in medium 32 containing glutamate was transferred to medium 22 containing no glutamate. Therefore, the suggested effects of glucose and glutamate are not conclusive at present.

\section{DISCUSSION}

A glutamate-producting bacterium, Brevibacterium flavum, was found to be capable of uptake and concentration of glutamate into the cells. Glutamate uptake was stimulated by $\mathrm{K}^{+}$and also by $\mathrm{Na}^{+}$. These cations did not affect the affinity for the substrate but increased the maximal uptake rate. In contrast with the above facts, it has been reported for the glutamate uptake in $E$. coli, which was similarly facilitated by both $\mathrm{K}^{+}$and $\mathrm{Na}^{+}$, that $\mathrm{K}^{+}$and $\mathrm{Na}^{+}$increased the maximal uptake rate and the affinity of the uptake system, respectively, and that these effects were synergistic. $^{12)}$

Although threonine uptake by $B$. flavum was found to depend on an $\mathrm{Na}^{+}$concentration gradient, ${ }^{11)}$ glutamate uptake can not be regarded as being coupled with the concentration gradients of these cations, because the uptake was not inhibited by valinomycin or gramicidin. On the other hand, almost total loss of the ability of cells to transport glutamate occurred with CCCP, an uncoupler of oxidative phosphorylation.

Glutamate uptake was competitively inhibited by aspartate specifically and completely, and moreover aspartate uptake was inhibited by glutamate similarly. Therefore, both glutamate and aspartate seem to be transported into cells by a common system. This is similar to the case of Streptococcus faecalis ${ }^{13,14)}$ but different from that of E. coli. ${ }^{15)}$ In view of the fact that inhibition by amino acids other than aspartate hardly occurred and inhibition by structural analogues was very weak in comparison with that by aspartate, the uptake system appears to be highly specific for glutamate and aspartate.

Glutamate uptake activity of B. flavum depended on the culture medium. The uptake activity increased with reduction of glucose and $\mathrm{NH}_{4}{ }^{+}$concentration and increase of glutamate concentration in the culture medium (medium 32). The activity of cells cultured in acetate medium was higher than that in glucose medium. Therefore, glutamate formation from glucose would be affected by the glutamate uptake activity at late stages of the culture where glucose concentration decreases and the formation from acetate would be more strongly affected than that from glucose.

It has previously been reported that six strains of mutants which did not grow on glutamate showed higher glutamate productivity than the parent but had all the glutamate metabolizing enzymes. Therefore, these strains were presumed to lack the transport system for glutamate. ${ }^{1)}$ In fact, a marked decrease in $V_{\mathrm{m}}$ values of the glutamate uptake activity was observed for four strains of the six and seems responsible for the lack of ability to grow on glutamate. Then, it may be concluded that these lower activities of glutamate uptake in the mutants reduce recapture of glutamate excreted and, therefore, provide lower intracellular concentrations of glutamate at steady state, which, in turn, promote escape from the feedback control of the biosynthesis and increase the glutamate production.

On the other hand, four of these six mutants showed increased $\mathrm{Km}$ values for the glutamate uptake activity. However, the concentration of glutamate in the medium used for testing the ability to grow on glutamate and that accumulated in the glutamate-producing medium were 53 and $120 \mathrm{~mm}$ respectively, much higher than these $\mathrm{Km}$ values. Therefore, the increase in $\mathrm{Km}$ 
values does not seem to cause a decrease in glutamate uptake under these conditions, or to affect the growth on glutamate as well as the production of glutamate.

Acknowledgment. The authors are indebted to Dr. T. Akashi and Dr. Y. Hirose of the Central Research Laboratories for their encouragement during this work.

\section{REFERENCES}

1) I. Shiio, H. Ozaki and M. Mori, Agric. Biol. Chem., 46, 493 (1982).

2) I. Shiio, S. Otsuka and M. Takahashi, J. Biochem., 51, 56 (1962).

3) I. Shiio, K. Narui, N. Yahaba and M. Takahashi, $J$. Biochem., 51, 109 (1962).

4) I. Shiio, S. Otsuka and N. Katsuya, J. Biochem., 53, 333 (1963).
5) I. Shiio and H. Ozaki, J. Biochem., 68, 633 (1970).

6) I. Shiio and K. Ujigawa, J. Biochem., 84, 647 (1978).

7) I. Shiio and K. Ujigawa-Takeda, Agric. Biol. Chem., 43, 2479 (1979).

8) I. Shiio, H. Momose and A. Oyama, J. Gen. Appl. Microbiol., 15, 27 (1969).

9) I. Shiio and K. Ujigawa-Takeda, Agric. Biol. Chem., 44, 1897 (1980).

10) I. Shiio, M. Mori and H. Ozaki, Agric. Biol. Chem., in press.

11) I. Shiio, R. Miyajima and N. Kashima, J. Biochem., 73, 1185 (1973).

12) Y.S. Halpern, H. Barash, S. Dover and K. Druck, J. Bacteriol., 114, 53 (1972).

13) K. G. Reid, N. M. Utech and J. T. Holden, J. Biol. Chem., 245, 5261 (1970).

14) N. M. Utech, K. G. Reid and J. T. Holden, J. Biol. Chem., 245, 5273 (1970).

15) Y. S. Halpern and A. Even-Shoshan, J. Bacteriol., 93, 1009 (1967). 